\title{
Analysis on the Path of Strengthening the Socialist Core Values Abased on the Accreditation of Engineering Education in China
}

\author{
Zhang Weijie, Song Xinquan* \\ School of Food and Biological Engineering, Jiangsu University, Zhenjiang, China
}

Email address:

wenyangxinquan@163.com (Song Xinquan)

*Corresponding author

To cite this article:

Zhang Weijie, Song Xinquan. Analysis on the Path of Strengthening the Socialist Core Values Abased on the Accreditation of Engineering Education in China. Science Journal of Education. Vol. 5, No. 2, 2017, pp. 45-49. doi: 10.11648/j.sjedu.20170502.12

Received: February 10, 2017; Accepted: February 28, 2017; Published: March 21, 2017

\begin{abstract}
It is an important measure to integrate the socialist core values into the whole process of national education. Engineering education accreditation is an important evaluation system for the development of Engineering Specialty in china, which needs the socialist core values. However, there are some problems on the establishment of the engineering education. It is lack of coordination in departments. Colleges should integrate the socialist core values into the engineering education accreditation from the perspective of departmental coordination, teaching security and interdisciplinary, which forms engineering education with the Chinese characteristics.
\end{abstract}

Keywords: Socialist Core Values, Engineering Education Accreditation, Outcomes-Based Education

\section{Introduction}

Engineering accreditation is an important evaluation system and a professional accreditation institution to set up specialized accreditation of engineering education, which is helpful to guide engineering education. According to the latest statistics, it currently has 1219 undergraduate colleges in China. The number of undergraduate students enrolled is 5247875 in the engineering colleges, which accounts for 33.2 percent of the total number ordinary undergraduate students (15766848) [1]. Engineering students are distributed in all walks of life. It is related to national economic development and social stability. Therefore, the students' education of socialist core values is not only helpful for students to establish correct world-views, life-views and values-views, which have a great influence on the implementation of Chinese dream and building a harmonious society. So, how to effectively integrate socialist core values of education into the professional certification of education has become an important issue on current engineering education.

\section{The Characteristics of College Students' Values Education in China}

\subsection{The Intersection and Penetration of the Specialized Courses is Bad}

Traditionally, China's engineering education attaches great importance to theoretical teaching abased on the theory of science, which is divided into public basic courses and professional basic courses. The total credit is generally200, which is from freshman to junior. It means that most of the courses have been concentrated on the first three years. Undergraduate studies tend to focus more on professional learning. However, students' ideological education courses are arranged on the same time. A lot of engineering curriculums are difficulty for the students. So it has less time for students to learn ideological and political courses. Otherwise, students do attach less importance to it. The teachers are lack of pertinence because they are common course Teachers, which is a 
common phenomenon in china. The division of Arts and Sciences leads a lot of engineering students to rejecting learning the ideological and political course such as the Marx doctrine principle, modern history outline.

\subsection{There Are Only a Few of the Sources of Teaching Practice}

Compared with students of arts and sciences, engineering students are busy to do experiments and read less the social science books in spare time. They have obvious advantages in logical thinking and manual operation. However, they are not good at writing and reading and they are willing to spend more time to stay in the laboratory and the teaching building. There is less chances for them to participate in social practice [2].

\subsection{Engineering Accreditation Involves Many Departments}

There are many departments involved in engineering certification education. Ideological and political teachers and college instructors are the main force to guide college students' values education. However, due to the administrative division, the teachers of Ideological and political courses are located in other departments. With the shortage of teachers and teaching funds, it is difficult to teach students in small teaching, so the communication between teachers with students is mainly concentrated in the classroom and there are only a few chances to discuss issues in spare time, which does reduce the teaching quality. In the teaching process, teachers are still been as the leading position, which has a long time to reverse teaching status.

\section{The Status of the Value Education of Engineering College Students in China}

\subsection{There Are Few Opportunities for Students to Accept Engineering Ethics Education}

The so-called engineering ethics refers to the ethical phenomena and ethical issues which are closely related to the project activities [3]. Engineering ethics is a branch of ethics, which has developed for nearly half a century in the west, but it has just started in China. Engineering ethics education in a narrow sense refers to the ethics of professional engineers. But now, with the increase of the social division of labor, it began to expand to more groups. As the goal of cultivating engineering students, there are only a few colleges and universities to set up engineering ethics courses. By contrast, the education of engineering ethics is a very important course in many foreign countries such as the United States and Canada, which has begun to develop engineering ethics since the last century in 60 s and now set up a series of engineering specialized courses of engineering ethics.

\subsection{Departments of Engineering Accreditation Involved Is Lack of Coordination}

Engineering accreditation requires collaboration of various departments and the school. The most important principle of accreditation certification is the goal achievement. The goal is made by the university according to the engineering standards formulated by their own characteristics, which justify itself. The teachers of department and school should pay more attention and strive to meet the standard. But it is hard to ensure that teachers at other faculties can be in accordance with the standard in the teaching process. So, the effect of education depends on the cooperation between departments

\section{The Integration of Values-Education with Engineering Education Accreditation}

Engineering education accreditation has its own value appeal of college students' values, which expresses a wealth of engineering ethics. The socialist core values formally convey the essence of the socialist core value system, which have guided the various walks of life from the state, society and individual. The socialist core values integrated into engineering education certification system is the requirements of the materialist philosophy. It reflects the cognitive order from general to special and from the special to the general, which is the inevitable road from theory to practice [4]. Engineering education accreditation is a reference to the advanced engineering education, which is exotic. To make Chinese characteristics, it must combine the engineering accreditation method and China higher education reality, thus forming the China engineering accreditation standard comparable to "American Standard" and "European standard".

\subsection{The Visible Needs of the Core Values of Engineering Education Accreditation}

From the standards, procedures and ways, engineering Education Accreditation needs the socialist core values. It has obvious value expression and appeal of the core values in the standard, content and logical relationship.

In the 2015 edition of the general standards of engineering education accreditation, the paper puts forward the requirements of Engineering Students' education from the following three aspects: Engineering and society, environment and sustainable development."Engineering and society" and "environment and sustainable development" emphasizes that the engineering students should bear social responsibility. "The occupation standard" requires students to follow the requirements of professional ethics.

Socialist core values put forward the requirements from the state, society and individuality. At the national level, it emphasizes "prosperity, democracy, civilization and harmony" [5]. At the social level, it notes "freedom, equality, justice and rule of law". It is not difficult to see that the engineering education standards reflect obviously the socialist core values. The paper require the students that the solution of engineering practice and complex engineering problems should follow the requirements of society, health, safety, law and culture, and they could understand the responsibility, which is helpful to promote the sustainable development of 
the social environment. Firstly it embodies the respect of Engineering Education Accreditation of national laws and be consistent with the requirements on "ruling the country by law".

Secondly, it emphasizes the concept of the sustainable development, which reflects the importance of ecological civilization construction in our country. In the occupation standard, it notes that students could comply with the occupation morals and norms of Engineering in engineering practice and understanding their responsibility according to the qualities of humanities and social science, which is same with the core values about "professionalism, integrity requirements. In logic, the core value is produced from the state and society and used to direct individuals. The implications of the two are basically the same. The procedure of engineering education certification is from the "certification standard (including supplementary standard)" to "the college standard", which is also from the wide to deep in logic level. It allows the college making its own characteristics but not specifies the details, as long as the college could provide relevant evidence that their own certification standard certification is consistent with ideas, which means that college could justify their point. In general, the certification of engineering education has a significant need for the content and logical level of core values.

\subsection{The Invisible of the Core Values of Engineering Education Accreditation}

The purpose of Engineering Education Accreditation in China is in line with the intrinsic requirements of core values. The socialist core values are the strategic task of promoting the great cause of socialism with Chinese characteristics and realizing the great rejuvenation of the Chinese nation [6]. In the end, it reflects the core demands and value judgment of the present stage of China's socialism, its purpose is to guide the social from all walks of life to construct the socialist under the guidance of Chinese and realize the great rejuvenation of the Chinese nation, which is the ultimate goal of the core values and internal needs.

China's engineering education certification is bided in 2013, which applies for membership of the United States to join the agreement in Washington, and in 2016 officially became a member of the agreement. It received the national and community attention. The smooth progress of the engineering education certification gets the reasonable support of the country, the society and the departments at all levels. China's higher education should serve the socialist modernization and serve the people. As one of the important certification system of higher education, engineering education accreditation also undertakes this task. On the content, Engineering Education Accreditation should meet the needs of social development. In the mechanism, it aims to improve the quality of education and cultivate high quality talents. In theory, it is based on the theory of Outcomes-based Education (OBE). The higher education in China will realize the basic modernization of education, the basic formation of a learning society and into the ranks of human resources until 2020. (The National
Medium and Long Term Education Reform and Development Plan (2010-2020)). All of these is implicit demand of Engineering Education in China.

\section{The Ways of Strengthening the Socialist Core Values Abased on the Accreditation of Engineering Education in China}

\subsection{The Integration of the Socialist Core Values into the Engineering Education Certification Needs Departments to Work Together}

Certification procedure of Engineering Education in China is that the college submits "self assessment report" [2] firstly. Then the professional accreditation committee audits the report. At last, Experts will conduct on-site inspection. The certification involves many departments including the college, the school and the department, which needs a unified understanding of the engineering education and follows the uniform norms especially for teachers. The ideological and political philosophy course is commonly regarded as the first class but be taught by usually teachers in the other department. It demands that the curriculum must assign homework, set curriculum objectives and evaluate student performance reasonably on the professional certification. Instructors should actively participate in the certification process and organize students to join relevant activities, which is helpful to improve the teaching effectiveness. Moreover, the professional teachers being the main participants of certification should actively respond to the certification requirements and perform the standard strictly.

Improving teachers' quality could help to educate students from the management and profession. In the current teaching, many teachers fail to perform the duty of education about the ideological and values, who simply think that it is the responsibility of the ideological and political course teacher or instructors. More emphasis is placed on the application of theory and practice in the field of engineering education. Therefore, teachers should also teach these issues related to engineering ethics, which explain complex engineering problems under the requirements of the core values and let students understand the correct value.

\subsection{It Should Pay Attention to the First Class and Enrich the Practice Teaching Form}

In College, all-round development is the ultimate goal of education. Morality aims to help students mainly set up the correct world-views, life- views and values- views [7]. The ideological and political curriculum becomes the first place of moral education. The effect of teaching is of great value to the education of core values. Teachers of Ideological and political courses should combine the profound theoretical and practical problems, in order that students can understand the development of the society profoundly and understand the splendid cultural heritage of our country, 
and form the cultural self-confidence, which has a profound understanding of the necessity of the Chinese socialist road choice and the task constructing socialism with Chinese characteristics.

In the traditional teaching, teachers are instructors while students are passive recipients. So, Teachers should encourage students to explore independently give full play to the initiative, according to the engineering characteristics, let students understand the connotation of the core values in teaching practice and knowing practice. Freshman sophomore should pay attention to the ideological and political course of learning, and it depends on the situation and policy class to allow students to continue to learn the knowledge of ideological and political education for the junior.

It should integrate the socialist core values into the practical teaching. To fully explore the core values of educational resources in practice, it could actively explore educational resources such as corporate culture, the establishment history of the company. The difference between engineering and other professional is that engineering education is closely linked with production. So, in the teaching, teachers attach more importance to professional practice, which is generally divided into curriculum design, professional practice and factory practice. The focus of engineering education accreditation is about to assess how well the students have mastered the knowledge of engineer. However, traditional engineering practice emphasis the form but ignore connotation. It is difficult for students to carry out their knowledge, if they are only allowed to visit the factory. Otherwise, it should encourage teachers to put knowledge into production, because the combination of production with teaching is an important form of cooperation between universities and enterprises. A group of outstanding teachers convert the theoretical achievements into products, which is a good show of practice teaching.

\subsection{It Should Pay Attention to the Cross Discipline, Which Contribute to Theoretical and Practical Innovation}

In the traditional teaching, the engineering professional teachers do not attach importance to the ethic education. This is a misunderstanding of teaching and also a misreading of social reality. Food safety has become the focus of national attention. Copycat products blossom everywhere. More and more social problems are concerned now, which directly related to engineering ethic education. This is not only a social problem but also reflects the lack of engineering ethics education in china. These enterprises are in bad faith without considering their own the liability consciousness and legal awareness. Because they only pay attention to pursuing economic profits but ignore the constraints of ethics. By contrast, some enterprises gradually grow adhering to the enterprise culture that the spirit of ingenuity has been an important part of their corporate culture.

Professional teachers actively explore the core values education in engineering education accreditation. The so-called open nonlinear education mode is based on the discipline with the characteristics of the specialty and pay attention to the interdisciplinary [8]. The core values education is political science. To combine the political education and engineering education is conducive to the realization of theoretical innovation. Students are the core of engineering education accreditation and are the important components of certification. As an important component of the value education, college instructors knowing more about the situation of the school should organize the educational activities with the professional characteristics and give full play to the role of the second classroom in the core values education. In the "college instructor professional ability standard", instructors should be in professional and specialized development and need to do theoretical and practical innovation, which become the inevitable career development [9]. Combining the connotation of college engineering certification and Ideological and political education has become a reference way.

In brief, engineering education accreditation is the direction of development of Engineering Education in china, which is a student centered education. Student management is a critical part of Engineering Education Accreditation in china [10]. Therefore, it is very important to promote the high quality of engineering education under the guidance of core values. However, the Engineering teaching in our country remains many problems in the education standards of core values and practice system. Therefore, it has certain significance integrate the core value into the engineering education accreditation, which could provide the reference for the same school from the perspective of the coordination of the departments in colleges, discipline-crossing innovation and the practice teaching.

\section{Acknowledgement}

This work has been sponsored by Jiangsu University specific project on Ideological and political education for college students (Grant No: JDXGSB201607).

\section{References}

[1] Statistical yearbook of china, the State Statistical bureau, [EB/OL]. (2015) [2016-12-21], http://www.stats.gov.cn/tjsj/ndsj/2016/indexch.htm.

[2] Spady, WG. 1994. Outcome-based Education [M]. Critical Issues and Answers. Arlington. American Association of School Administrators.

[3] Philosophy of engineering and engineering research [M], Li Bocong, Beijing: Science Press, p146.

[4] Spady, WG. 1997. Paradigm lost. Reclaiming America's educational future [M]. Arlington. American Association of School Administrators.

[5] The National Medium and Long Term Education Reform and Development Plan (2010-2020) [EB/OL]. (2010-7-29)[2016-11-21], http://www.moe.edu.cn/publicfiles/business/htmlfiles/moe/mo e_838/201008/93704.html. 
[6] Liu Shulin. On the socialist core values of several important $[\mathrm{J}]$. ideological and theoretical education Herald, 2014, (09): 60-67.

[7] Liu Yunlian. [J]. education ideological education guide, strengthen college students' socialist core value under the new situation, 2014, (05): 106-109.

[8] Yu Tian, Liu Shaoxue. From external evaluation to self improvement: the reform and Enlightenment of American engineering education accreditation standard EC2000 [J]. higher engineering education research, 2014, (06): 28-34.
[9] Xu Haifeng. Several issues on the study of the socialist core values need to be explored in depth [J]. socialism research, 2014, (): 26-32.

[10] Wang Lili, Zhang Lin. Construction of socialist core values of contemporary college students [J]. Journal of Northeast Normal University (PHILOSOPHY AND SOCIAL SCIENCES EDITION), 2014, (): 44-47. 